\title{
REVIEW
}

\section{An Integrative Review of Approaches Used to Assess Course Interventions}

\author{
Eytan A. Klausner, $\mathrm{PhD},{ }^{\mathrm{a}}$ Adam M. Persky, $\mathrm{PhD}^{\mathrm{b}, \mathrm{c}}$ \\ ${ }^{\text {a }}$ South College, School of Pharmacy, Knoxville, Tennessee \\ ${ }^{\mathrm{b}}$ University of North Carolina at Chapel Hill, UNC Eshelman School of Pharmacy, Chapel Hill, North Carolina \\ ${ }^{\mathrm{c}}$ Associate Editor, American Journal of Pharmaceutical Education, Arlington, Virginia
}

Corresponding Author: Eytan A. Klausner, South College, School of Pharmacy, 400 Goody's Ln., Knoxville, TN 37922. Tel: 865288-5835. Email: eklausner@south.edu

Submitted September 20, 2021; accepted January 21, 2022; ePublished January 2022

Objective. The objectives of the review are to (1) describe the utility of approaches used for the assessment of course interventions in pharmacy education; and (2) provide recommendations that may guide faculty members in their future scholarship of teaching and learning (SoTL) efforts that encompass assessment of course interventions.

Findings. Thirty-four articles that included educational interventions published between 2016 and 2020 in the American Journal of Pharmaceutical Education and Current in Pharmacy Teaching and Learning were selected for analysis. Those articles used various approaches for the assessment of course interventions. In the order of decreasing frequency of use, those methods were surveys, student academic performance, student evaluations, mixed quantitative- and qualitative methods, pre- and post-test, and learning analytics.

Summary. The use of more than one assessment approach, ie, triangulation, and multiple student cohorts, are advantageous. When multiple cohorts are used, it is beneficial to present the students' demographic information. Student academic performance should be part of an assessment of course interventions whenever relevant. Surveys about student perceptions and confidence may contribute to the assessment of course interventions. However, since the information collected is subjective and is usually unrelated to student learning, such an approach should be coupled with other assessment approaches that reflect student learning, such as academic performance and/or a pre- and a post-test. Depending on the research question, qualitative methods and learning analytics may also be a part of the assessment of a course intervention.

Keywords: course intervention; course assessment; student evaluations; measures of learning; learning analytics

\section{INTRODUCTION}

The Scholarship of Teaching and Learning (SoTL) encompasses studies on various topics such as student learning, assessment, curriculum, health disparities and cultural competency, wellness, and professionalism. ${ }^{1} \mathrm{~A}$ certain type of SoTL study involves the description and assessment of courses, ${ }^{2}$ and in particular courses that underwent an intervention to improve learning outcomes or were newly implemented. Since after several years of teaching faculty members develop expertise in the course instruction and may experiment in introducing classroom innovations, this type of study may serve faculty members who are novices to SoTL as a possible gateway to the discipline. Moreover, faculty members who have already experimented with SoTL but have not yet published their teaching innovations may wish to expand their SoTL program by doing so. As they consider the assessment of their instructional innovations, faculty members should be aware of the following approaches:

Academic performance - Academic performance in courses usually includes student deliverables, such as assessment scores and/or course final letter grades. ${ }^{3}$ This approach is convenient because the SoTL assessment is embedded in the course. ${ }^{4}$

Pre- and post-test - This quantitative approach involves the administration of a test prior to and after an intervention to the same group of students. ${ }^{3,5}$ An advantage of this approach is that it may confirm that knowledge was acquired during the intervention. ${ }^{6}$ Disadvantages of this approach are that it does not allow conclusions whether the method is equivalent, superior, or inferior to other forms of instructions, and it may be difficult to conclude whether the effects are simply due to time (eg, student maturation) or the intervention. ${ }^{5}$

Surveys - Surveys may be administered after an intervention, or as a pre- and post-survey. ${ }^{3,7,8}$ Surveys may include quantitative questions ${ }^{9,10}$ (eg, Likert scale), and/or questions in the form of free-text items to provide written feedback that can be assessed in qualitative methods. ${ }^{3,8}$ Surveys frequently inquire about subjective, self-reported measures such as student perceptions or attitudes regarding an intervention, ${ }^{8,9}$ or changes in confidence levels regarding 
abilities that were acquired during an intervention. ${ }^{3}$ Validated survey instruments may be obtained from the literature or via certain vendors. However, in the cases of course intervention because the intervention is very specific, educational researchers will most likely need to design a survey. ${ }^{8}$ A disadvantage of surveys is that because the information collected is subjective ${ }^{8}$ it may not reflect student learning, ${ }^{5}$ and better understanding and enhancement of student learning were noted as the main reasons behind SoTL. $5,9,11$

Student evaluations of teaching - Similarly to surveys, student evaluations may include quantitative and qualitative questions. Differences in the information collected among various institutions affect the possible contribution of the evaluations to the assessment of course interventions. Some institutions may allow a researcher to add items related to the intervention into the student evaluations. ${ }^{3,12}$ An advantage of student evaluations is that they are administered every year. In the case of a course intervention, this allows the researchers to use evaluations that were collected prior to the intervention as a control group. Institutional Review Boards (IRBs) may approve the use of student evaluations (as well as other course-related data) that were collected before the research was initiated as a usage secondary to its routine utilization for educational purposes. ${ }^{4,8}$ A disadvantage of student evaluations is that by nature they collect subjective information, which is not directly linked to student learning. ${ }^{3,13}$ Additional disadvantages are that evaluations are affected by gender and race of the faculty member; ${ }^{3}$ unlike surveys that are tailored toward a certain intervention, student evaluations inquire about general course attributes; and particularly in the cases where the intervention is only part of a course, the information collected regarding an intervention may be limited.

Qualitative studies - Qualitative study designs may encompass a collection of written information such as student reflections or data collected from interactions with students such as interviews or focus-groups. ${ }^{8,10,14}$ Responses to freetext items ${ }^{9}$ in surveys or student evaluations may also be analyzed in qualitative methods, such as thematic analysis. ${ }^{8,10,12,}$ ${ }^{14-16}$ The design and execution of qualitative studies require expertise that may be more specialized than other described methods. ${ }^{5,14}$

Mixed methods - This term refers to the combination of quantitative and qualitative methods in the same study design. ${ }^{2,9,10,14}$ It was suggested that the use of mixed methods is advantageous as it can potentially provide a wider view of the research question by allowing triangulation of findings., 8

Learning analytics - A standard definition of learning analytics is the "measurement, collection, analysis and reporting of data about learners and their contexts, for purposes of understanding and optimizing learning and the environments in which it occurs". ${ }^{17}$ Unlike academic performance that usually includes grades or performance data, learning analytics refer to the collection and analysis of data about learners and their environments for the purpose of understanding and improving learning. For example, correlating frequency of learning activities such as software usage data with academic performance, ${ }^{18}$ or grouping of assessment questions into topics with the subsequent correlation of student success rates in solving the questions with various teaching approaches. ${ }^{19}$ The utilization of learning analytics in SoTL is more recent, and it may contribute to the assessment of course interventions. ${ }^{9,17}$

We conducted a literature search in the pharmacy education literature to identify articles that may support faculty members engaged in SoTL. ${ }^{6,7}$ This search did not uncover a review article that specifically focuses on the assessment of course interventions, or suggests better practices for the assessment of course interventions. Therefore, this review article aims to (1) describe the utility of approaches used for the assessment of course interventions in pharmacy education; and (2) provide recommendations that may guide faculty members in their future SoTL efforts that encompass assessment of course interventions.

\section{METHODS}

A literature search was conducted, primarily based on article titles, in the websites of the journals, American Journal of Pharmaceutical Education and Currents in Pharmacy Teaching and Learning. The search was limited in time from August 2016 to August 2021 to capture contemporary methodologies. The aim was to identify articles from each of the two journals about interventions in existing courses or the implementation of new courses. Due to a limitation on the number of references in the article, it was decided that for this part of the review 17 articles will be cited from each journal and that those 17 articles will be similarly divided between articles about interventions in existing courses and articles regarding the implementation of new courses. While considering this structural design, the main criterion for inclusion was time, and more recent articles were preferred. Articles about experiential education and objective structured clinical examinations (OSCEs) were excluded. A few additional articles were excluded because of unclear methodologies. Next, a literature search was conducted in Google Scholar and Educational Resources Information Center (ERIC) to identify articles that provide general information regarding the assessment of course interventions outside of pharmacy or health care education. The terms used for this search were SoTL research design, SoTL getting started, SoTL learning analytics, and student evaluations teaching effectiveness. Google Scholar was also used to identify articles that cite some of those articles that were previously identified. Moreover, a search was conducted on amazon.com using the term 
scholarship of teaching and learning to identify books about SoTL. Book chapters regarding the assessment of course interventions from books that were not part of the library collection were ordered via an inter-library loan service.

\section{RESULTS AND DISCUSSION}

Table 1 describes approaches used in articles $(n=17)$ to assess intervention in existing courses, and Table 2 describes approaches in articles $(n=17)$ to assess the implementation of new courses. Table 3 summarizes the various approaches that were used to assess course interventions with respect to the frequency of use. As seen in Table 3, the approaches to assess course interventions, in descending order of frequency of use, were survey administration, academic performance, student evaluations, mixed methods, pre- and a post-test, and learning analytics.

The review focused on a certain type of articles where researchers describe innovations in their own teaching. The literature suggests that an instructor's own teaching is an appropriate place to start SoTL efforts, ${ }^{2,11}$ that conducting SoTL on one's own teaching is common, ${ }^{2,4}$ and that such studies are important for the SoTL discipline. ${ }^{5}$

As pharmacy educators who wish to conduct SoTL frequently encounter challenges related to their lack of formal training in SoTL, ${ }^{7}$ the challenge of choosing appropriate methodologies was also noted for SoTL beyond pharmacy education. ${ }^{11}$ An example of such a challenge is the design of an appropriate control group. ${ }^{2}$ The current review revealed that it is common to use cohorts prior to the intervention as a control group. ${ }^{19-24}$ Changes between the cohorts beyond the intervention may hamper such a use. ${ }^{3,21}$ With the lack of such changes, it suffers from a limitation that no two classes are identical, even when the course is taught by the same instructor who presents the same lectures. ${ }^{5}$ Nevertheless, a comparison with previous cohorts is still an acceptable approach despite its inherent limitations. ${ }^{4}$

The included studies used, on average, more than two approaches to assess the course intervention. Triangulation was already suggested in the literature regarding SoTL of pharmacy ${ }^{10}$ and beyond as a valid approach, which may be advantageous. ${ }^{8,9}$

Academic performance was used most commonly. Examples of metrics that were used to study the academic performance were average final course scores, ${ }^{20,25-27}$ a range of final course scores, ${ }^{28,29}$, average student scores on various course assessments such as examinations, ${ }^{20-22,24-26,30,31}$ quizzes, ${ }^{20,23,32,33}$ or other assignments. ${ }^{20,26,27,33,34}$ In a few cases where the course intervention was limited to a certain part of the course the metric used to assess academic performance was not the entire assessment but the score on a group of questions that were related to the intervention. ${ }^{19,23,30}$ Final course letter grades $^{20,21,25}$ and the number or percentage of students who passed or failed examinations ${ }^{21,22,31}$ were also used as metrics for academic performance. Examples of other, less common metrics that were used are overall first attempt passing rate on quizzes, ${ }^{23}$ and quality of reflection activities. ${ }^{29}$ The use of academic performance is convenient as it is collected as part of the course that is under study. ${ }^{4}$ Compared to the other approaches, academic performance is a better proxy of student learning. ${ }^{3}$

A different approach that may be used as a proxy for student learning is the pre- and post-test, which was not commonly used in the studies (Table 3 ). In the case where the intervention was only part of the course, items from the final examination related to the intervention served as a post-test and were administered as the pre-test. ${ }^{3,34}$ However, even in the case of the implementation of a new course, there is no need to use the entire final examination as the post-test that should also be administered as a pre-test. ${ }^{4}$ Due to time constraints related to the pre-test, it is possible to randomly select items from the final examination for the administration of a pre-test.

Survey administration is a valid approach to assess a course intervention. Most of the articles that we analyzed relied on instructor-developed surveys and not on validated surveys obtained from a source external to the study. Those surveys inquired students about subjective measures such as their perceptions and attitudes regarding the intervention, satisfaction and/or interaction with the intervention, or confidence regarding topics covered in the intervention (Table 3). It was common for surveys to include free-text items ${ }^{12,15,16,18,23,27,34-37}$ that in a few studies were used for a qualitative thematic analysis. ${ }^{12,15,16}$ Frequently, the description of survey results included the survey questions and student responses. $^{12,15,18,23,27,31-34,38-44}$ Depending on the research question there may be a need to administer a pre- and a postsurvey. This may be particularly important when the survey measures changes from a baseline prior to the intervention. Hence, in all the studies that appear in Table 3 that included a survey about confidence the survey was administered as a pre- and post-survey. As suggested in the literature ${ }^{45}$ and conducted in some of the studies that we analyzed, ${ }^{28,32,35,39,42}$ it is advantageous to pretest the survey on a group of students who are potential responders to the survey.

Some of the studies in Table 3 that included survey administration collected basic demographic information such as the respondents' age and/or gender. ${ }^{27,28,30,31,38,41,42,46}$ Several studies asked about past experiences related to the intervention, ${ }^{27,30,32,33,41,42}$ such as prior participation in a course that may have provided background information to the students. ${ }^{46,47}$ An advantage of a report regarding demographics ${ }^{3}$ is that it enables a better understanding regarding the generalizability of the study, ${ }^{5}$ in particular when studies regarding a course intervention by nature almost always describe a course in one institution, with only one exception in the articles that we analyzed. ${ }^{48}$ A report regarding demographics, 
including measures of academic performance such as incoming Grade Point Average (GPA) and/or cumulative GPA, should also be considered when one or more cohorts prior to the intervention are used as a control group to ascertain that the classes are similar in that respect. ${ }^{7}$

Student evaluations may also play a role in the assessment of course interventions. The three major approaches in the description of student evaluations were to generally describe the evaluations as a whole or in part; ${ }^{15,22,24,30,36}$ to present evaluation scores; and/or to delineate the students' written comments. In the presentation of evaluation scores, various studies provided different metrics, such as one score that averaged all items regarding the instructor ${ }^{20,21}$ or the $^{25,36}$ course ${ }^{20,26,32}$ average scores for different items regarding the course ${ }^{24,28,29,32}$ or both the course and the instructor; ${ }^{25,36,49}$ or average scores for one item regarding the course. ${ }^{15,30}$ In the presentation of student comments the main approaches were to provide a summary of the comments, ${ }^{20-22,24,26,30}$ excerpts from the comments, ${ }^{25,26,28,29,44}$ or both. ${ }^{49}$ One study, which collected student evaluations from seven years, conducted a qualitative thematic analysis to excerpts from student evaluation $\mathrm{s}^{29}$ as mentioned above for responses to free-text items in surveys. Several studies mentioned not only the positive student comments but also the negative or opportunities for course improvement. ${ }^{20,24,25,44}$ From a SoTL perspective, there may be greater significance to information that stems from student responses to free-text items compared to numerical values. The reason is two-fold: First, free text yields much richer data that can help identify causes or rationale. Second, student evaluations have come under scrutiny as there may be various biases as described above. ${ }^{13}$

As seen in Table 3, with one exception ${ }^{29}$ all studies that utilized qualitative methods essentially used mixed methods as they also used quantitative methods. Qualitative methods utilized can generally be divided into those that rely on written documentation, which was more commonly used, and those where the information was collected through interaction with students, such as interviews ${ }^{39,42}$ or focus groups. ${ }^{30,48}$ Documents used for qualitative analysis were student reflections, ${ }^{43,48}$ student responses to free-text items in surveys, ${ }^{12,15,16}$ and student evaluations as mentioned above. ${ }^{29}$ In one study, student responses to free-text items in their evaluations were compared to results obtained from focus groups. ${ }^{30}$ Qualitative methods were less commonly used than most other approaches to assess course interventions. As mentioned above, this may be related to the fact that mastery in the use of qualitative methods requires a more specialized training, and/or to the possibility that the training of pharmacy educators in basic- or clinical sciences leads them to prefer quantitative research, which may be subject to statistical analyses. ${ }^{2,9}$

Among the studies that we analyzed, the (relatively uncommon) use of learning analytics included various components. One study assessed the number of students who interacted with the intervention by extracting from a freeware information about the extent of completion of optional exercises. Subsequently, usage data was correlated with scores on examination questions relevant to the intervention. ${ }^{18}$ A more traditional approach in the usage of learning analytics was described in a study that used the Learning Management System to obtain student grades from select courses before, simultaneous with, and after the intervention to compare students who participated in an intervention to those who did not. ${ }^{37} \mathrm{~A}$ similar analysis was conducted in a study regarding a journal club elective that assessed the effect of participation in the course on overall Pharmacy Curriculum Outcomes Assessment (PCOA) scores, PCOA scores in two certain areas, and overall course scores in three courses, which were administered after the elective. ${ }^{47}$ In a recent study, learning analytics were applied to pharmacy calculations to calculate the success rates of students in solving examination questions based on topics and to correlate those success rates with the approach that students used to solve calculation questions. The design of this study was atypical as it relied on the instructor teaching two approaches for problem-solving to the entire class and the students choosing which approach to use for each topic. ${ }^{5018,19}$

Other studies used approaches for assessment of intervention that were more specific to their courses. A study about a Sterile Compounding course included a metric of changes in laboratory expenses. ${ }^{24}$ An elective entitled Pharmaceutical Care in Indigenous Health assessed its ability to attract students and meet the cap on the number of participants since the course inception. ${ }^{29}$

A limitation of the review is that the number of articles that we analyzed was limited. Moreover, considering the design that we used to select articles for analysis (similar number of articles from each journal, and for interventions in existing courses versus the implementation of new courses), articles were selected mainly on a chronological basis.

However, it is possible that other authors might have selected different articles. Nevertheless, the conclusions would have likely been very similar even with a slightly different selection of articles. Another limitation is that due to the relatively small number of articles that we analyzed, and the described structural design, we were unable to track changes in the approaches used for the assessment of course interventions over time.

\section{CONCLUSION}

The analysis of articles about the assessment of course interventions that we conducted leads to the following recommendations:

- We recommend the use of more than one assessment approach, ie, triangulation, to assess course interventions. 
- We recommend the use of multiple cohorts whenever possible, particularly when the class size is relatively small (eg, < 100 students).

- When comparing a course after intervention to a historical control, we recommend the comparison of student academic performance and student evaluations. If during multiple course iterations some of the examination questions are unchanged, then question tagging may be used to study student performance on those questions. Institutional review boards may approve such studies not only prior to the intervention (with a retrospective component of previous cohorts) but also after the intervention was completed. However, the opportunity to use additional assessment approaches such as surveys or a pre- and post-test may not be available at that point.

- If the intervention is optional in a required course, or the intervention is an elective course, non-participants may be used as a control group. In addition, academic performance on blocks from the same course that did not undergo the intervention or on a different course from the same course sequence that the instructor taught without intervention may also be used as a control group.

- When multiple cohorts are used, it is advantageous to present demographic information such as incoming GPA or cumulative GPA to assess similarity in baseline skills and knowledge. An advantage of cumulative GPA over incoming GPA is that the former represents academic performance from the same institution and therefore provides more consistent information regarding the different cohorts.

- Student academic performance should be part of an assessment of course intervention whenever relevant. When the intervention is a new course then assessment scores and/or final course scores may be used. Final course letter grades, a less sensitive metric that can still demonstrate the class's overall performance, may also be used. When the intervention is a change that affects only part of an existing course, then student performance on assessment questions related to the intervention may be compared to their performance on assessment questions unrelated to the intervention. However, adequate sampling of that topic would be needed.

- A pre- and a post-test may be an acceptable assessment approach for course interventions when there is a control group such as students from a different cohort. Without the control condition a pre- and a post-test design may demonstrate student learning, but not the extent of intervention effectiveness.

- Surveys about student perceptions and confidence may contribute to the assessment of course interventions but rarely are sufficient to demonstrate improved student learning. A survey about confidence levels should be administered both before and after the intervention to identify possible changes.

- When using surveys, if the researchers are unable to find a validated survey that satisfies their specific needs, to enhance the validity of an instructor-developed survey it should undergo a thorough review by peers with subsequent pretesting on a group of student pharmacists. Such a survey may collect demographic information regarding previous student experiences related to the intervention (eg, prior participation in a course that provided background information to the students). Moreover, the presentation of demographic information such as age and/or gender may demonstrate the possible generalizability of the study.

- Qualitative methods may provide a deeper understanding of the student experience. Hence, depending on the research question, qualitative methods may be used as the only assessment strategy or in a mixed-methods design. Since the design and execution of such studies require specialized training, it is desirable to consult or collaborate with researchers that are experienced in such studies and/or refer to published guidance on reporting qualitative data.

- Student evaluations may be added as a minor contributor to the assessment of course interventions. A summary of student comments with the optional addition of excerpts, with or without opportunities for course improvement, may be provided. Numerical values are most helpful when the intervention relates to an entire existing course (eg, a course overhaul) and the previous cohorts serve as a control group.

- Depending on the research question, learning analytics may be a part of the assessment of a course intervention. Researchers should be aware of data (including usage data) that may be obtained from their Learning Management System, online examination software, platforms that are used by the institution (eg, for lecture recording, remote teaching, or student polling), and other applications that may be used in their courses; and to opportunities to use such data. It is noteworthy that not all institutions have access to the same analytics. The lack or limited accessibility to appropriate data may prevent the execution of some potential analyses or research projects.

- Assessment of intervention in some specific courses may be conducted by more unique approaches. 


\section{REFERENCES}

1. Klausner EA, Pitchford KD, Schmidhammer JL, Phillips BR. Pharmacy, nursing, and physician assistant studies student self-report and perceptions regarding classroom etiquette. Pharm Educ. 2021;21(1):194-202.

https://doi.org/10.46542/pe.2021.211.194202

2. Rowland SL, Myatt PM. Getting started in the scholarship of teaching and learning: A "How to" guide for science academics. Biochem Mol Biol Edu. 2014;42(1):6-14. https://doi.org/10.1002/bmb.20748

3. Clipperton JM, Franco J, Nordyke S, Shaffer-O'Connell M, Wood F. SOTL research design for assessment of interventions. APSA Preprints. 2020:This content is a preprint and has not been peer-reviewed.

https://doi.org/10.33774/apsa-2020-gwfl0

4. Dewar J, Bennett C, Fisher MA. The Scholarship of Teaching and Learning: A Guide for Scientists, Engineers, and Mathematicians. Oxford, United Kingdom: Oxford University Press; 2018.

5. $\quad$ Bartsch RA. Designing SoTL studies - part I: Validity. New Dir Teach Learn. 2013;136:17-33. https://doi.org/10.1002/tl.20073

6. Persky AM, Romanelli F. Insights, pearls, and guidance on successfully producing and publishing educational research. Am J Pharm Educ. 2016;80(5):75. https://doi.org/10.5688/ajpe80575

7. Kennedy DR, Beckett RD, O'Donnell LA. Strategies, ideas, and lessons learned while engaging in SoTL without formal training. Am J Pharm Educ. 2020;84(1):7702. https://doi.org/10.5688/ajpe7702

8. McKinney K. Enhancing Learning through the Scholarship of Teaching and Learning: The Challenges and Joys of Juggling. San Francisko, CA: Anker Publishing Company, Inc.; 2007.

9. Divan A, Ludwig LO, Matthews KE, Motley PM, Tomljenovic-Berube AM. Survey of research approaches utilised in the scholarship of teaching and learning publications. Teach Learn Inq. 2017;5(2):16-29.

https://doi.org/10.20343/teachlearninqu.5.2.3

10. McLaughlin JE, Dean MJ, Mumper RJ, Blouin RA, Roth MT. A roadmap for educational research in pharmacy. Am J Pharm Educ. 2013;77(10):218. https://doi.org/10.5688/ajpe7710218

11. Felten P. Principles of good practice in SoTL. Teach Learn Inq. 2013;1(1):121-125.

https://doi.org/10.2979/teachlearninqu.1.1.121

12. Maher S, Hayden JC, Strawbridge JD, Gallagher PJ, Flood M. 'Both useful in their own way': Video podcasts and typed solutions as feedback on undergraduate pharmaceutical calculations skills assessment. Curr Pharm Teach Learn. 2020;12(4):367-77. https://doi.org/10.1016/j.cpt1.2019.12.021

13. Uttl B, White CA, Gonzalez DW. Meta-analysis of faculty's teaching effectiveness: Student evaluation of teaching ratings and student learning are not related. Stud Educ Eval. 2017;54:22-42.

https://doi.org/10.1016/j.stueduc.2016.08.007

14. Bush AA, Amechi MH. Conducting and presenting qualitative research in pharmacy education. Curr Pharm Teach Learn. 2019;11(6):638-650. https://doi.org/10.1016/j.cptl.2019.02.030

15. Alsharif NZ, Faulkner MA. Implementation of the pharmacists' patient care process in a medicinal chemistry course. Am J Pharm Educ. 2020;84(2):7556. https://doi.org/10.5688/ajpe7556

16. Diehl B, Dy-Boarman EA, Bottenberg MM, Mobley-Bukstein W, Patel A. Using a design-based research framework to refine a desirable difficulties activity for sterile compounding in a skills-based laboratory course.

Curr Pharm Teach Learn. 2020;12(2):189-192. https://doi.org/10.1016/j.cptl.2019.11.013

17. Bronnimann J, West D, Huijser H, Heath D. Applying learning analytics to the scholarship of teaching and learning. Innov High Educ. 2018;43(5):353-567. https://doi.org/10.1007/s10755-018-9431-5

18. Mospan GA, Gillette C. Using MyDispense to simulate validation of controlled substance prescriptions in a pharmacy law course. Curr Pharm Teach Learn. 2020;12(2):193-202. https://doi.org/10.1016/j.cptl.2019.11.014

19. Sumanasekera W, Turner C, Ly K, Hoang P, Jent T, Sumanasekera T. Evaluation of multiple active learning strategies in a pharmacology course. Curr Pharm Teach Learn. 2020;12(1):88-94.

https://doi.org/10.1016/j.cptl.2019.10.016

20. Kennedy DR. Redesigning a pharmacology course to promote active learning. Am J Pharm Educ. 2019;83(5):6782. https://doi.org/10.5688/ajpe6782

21. Kennedy DR. The effect of banning computers on examination performance in a first-year pathophysiology class. Am J Pharm Educ. 2019;83(10):7535. https://doi.org/10.5688/ajpe7535

22. Mitroka JG, Harrington C, DellaVecchia MJ. A multiyear comparison of flipped- vs. lecture-based teaching on student success in a pharmaceutical science class. Curr Pharm Teach Learn. 2020;12(1):84-87.

https://doi.org/10.1016/j.cptl.2019.10.014 
23. Mnatzaganian CL, Singh RF, Best BM, Morello CM. Effectiveness of providing video podcasts to pharmacy students in a self-study pharmaceutical calculations module. Am J Pharm Educ. 2020;84(12):7977.

https://doi.org/10.5688/ajpe7977

24. Monestime S, Thomas D, Hooper CD, Day T, Suzuki S, Martin RD. Instructional and assessment redesign of a sterile compounding course using immersive simulation. Am J Pharm Educ. 2020;84(2):7473.

https://doi.org/10.5688/ajpe7473

25. Bose DD. An elective course in cardiovascular electrophysiology for pharmacy learners. Am J Pharm Educ. 2016;80(8):130. https://doi.org/10.5688/ajpe808130

26. Linger RS. Design and implementation of an elective on the ethnopharmacology of Appalachia for the PharmD curriculum. Am J Pharm Educ. 2017;81(10):6100. https://doi.org/10.5688/ajpe6100

27. Perez A, Rabionet S, Bleidt B. Teaching research skills to student pharmacists in one semester: An applied research elective. Am J Pharm Educ. 2017;81(1):16. https://doi.org/10.5688/ajpe81117

28. El-Ibiary SY, Azizoddin A, Petrossian L, Gurney MK. Implementation and evaluation of a women's reproductive health pharmacy elective. Curr Pharm Teach Learn. 2018;10(8):1087-1096.

https://doi.org/10.1016/j.cptl.2018.05.007

29. Min J, Albon S, Leung L, Clarke A. Creating a pharmacy elective course in indigenous health. Curr Pharm Teach Learn. 2020;12(8):1004-1013. https://doi.org/10.1016/j.cptl.2020.04.010

30. Saba M, Metry I, Lucas C, Saini B. Evaluation of a flipped examination model implemented in a final-year undergraduate pharmacotherapeutics course. Am J Pharm Educ. 2019;83(3):6568.

https://doi.org/10.5688/ajpe6568

31. Zhang B, Kim S, Xiao Y, et al. A student initiative to implement peer-led study groups for a pharmacogenomics course: Evaluation of student performance and perceptions. Curr Pharm Teach Learn. 2020;12(5):549-557. https://doi.org/10.1016/j.cpt1.2020.01.013

32. Jacob B, Peasah SK. An elective course for student pharmacists on pharmaceutical industry practice. Am J Pharm Educ. 2019;83(8):7037. https://doi.org/10.5688/ajpe7037

33. Melody K, Harris EM, Grover AB. Development and evaluation of an elective course that incorporates a standard medication therapy management certificate program. Curr Pharm Teach Learn. 2018;10(8):1104-1112.

https://doi.org/10.1016/j.cptl.2018.05.008

34. Powers KC, Buffington TM, Contaifer D, Jr., Wijesinghe DS, Donohoe KL. Implementation of an active-learning laboratory in pharmacogenomics. Am J Pharm Educ. 2019;83(3):6605. https://doi.org/10.5688/ajpe6605

35. Austin D, Shivji A, Offei D. Analysis of a novel enrichment strategy for an integrated medicinal chemistry and pharmacology course. Curr Pharm Teach Learn. 2020;12(10):1201-1207.

https://doi.org/10.1016/j.cptl.2020.05.016

36. Spooner JJ, Kennedy DR. An elective course to foster interest in academic pharmacy career opportunities. Am J Pharm Educ. 2017;81(1):13. https://doi.org/10.5688/ajpe81113

37. Waite LH, Smith MA, McGiness TP. Impact of a problem-based learning elective on performance in nonproblem-based learning required courses. Curr Pharm Teach Learn. 2020;12(12):1470-1476.

https://doi.org/10.1016/j.cptl.2020.07.015

38. Arif S, Wang S, Lakada IY, Lee JY. An elective course to train student pharmacists to provide culturally sensitive health care. Am J Pharm Educ. 2019;83(8):7027. https://doi.org/10.5688/ajpe7027

39. Awaisu A, Khalifa S, Mottram D, Ahmed A, Stuart M. Instructional design and assessment of an elective course on the use of drugs in sport. Curr Pharm Teach Learn. 2018;10(8):1124-1131.

https://doi.org/10.1016/j.cptl.2018.05.020

40. Franko TS, II, Trombetta D. Impact of an innovative pain elective course on student beliefs and attitudes towards opioid medication use. Curr Pharm Teach Learn. 2018;10(9):1248-1263.

https://doi.org/10.1016/j.cptl.2018.06.002

41. Ledbetter E, Lau S, Enterline A, Sibbitt B, Chen AMH. A simulation activity to assess student pharmacists' knowledge and perceptions of oncology pharmacy. Am J Pharm Educ. 2020;84(5):7474.

https://doi.org/10.5688/ajpe7474

42. Mishra SD, Rebitch CB, Choi I. Exploring student perceptions and attitude towards various aspects of peer feedback in a pharmacotherapy course. Curr Pharm Teach Learn. 2020;12(6):701-708. https://doi.org/10.1016/j.cptl.2019.10.007

43. Robinson JD, Maslo TE, McKeirnan KC, Kim AP, Brand-Eubanks DC. The impact of a mental health course elective on a student pharmacist attitudes. Curr Pharm Teach Learn. 2020;12(7):885-892.

https://doi.org/10.1016/j.cptl.2020.02.011 
44. Whitman C, Kamath S, Lawrence S, et al. Design and implementation of a molecular imaging elective for thirdyear pharmacy students. Curr Pharm Teach Learn. 2020;12(2):132-141.

https://doi.org/10.1016/j.cptl.2019.11.006

45. Artino RA, Jr., La Rochelle JS, Dezee KJ, Gehlbach H. Developing questionnaires for educational research: AMEE Guide No. 87. Med Teach. 2014;36(6):463-474. https://doi.org/10.3109/0142159X.2014.889814

46. Rust C, Gentry WM, Ford H. Assessment of the effect of communication skills training on communication apprehension in first year pharmacy students - a two-year study. Curr Pharm Teach Learn. 2020;12(2):142-146. https://doi.org/10.1016/j.cptl.2019.11.007

47. Burris JN, Frederick EK, Malcom DR, Raake S, Shin M, Daugherty KK. Impact of a journal club elective course on student learning measures. Am J Pharm Educ. 2019;83(7):6827. https://doi.org/10.5688/ajpe6827

48. Woodard LJ, McKennon S, Danielson J, Knuth J, Odegard P. An elective course to train student pharmacists to deliver a community-based group diabetes prevention program. Am J Pharm Educ. 2016;80(6):106. https://doi.org/10.5688/ajpe806106

49. Cain J. A pharmacy elective course on creative thinking, innovation, and TED talks. Am J Pharm Educ. 2016;80(10):170. https://doi.org/10.5688/ajpe8010170

50. Klausner EA, Holt MJ. The use of dimensional analysis, ratio and proportion, and equations to solve pharmacy calculations problems. Curr Pharm Teach Learn. 2022;14(4):accepted.

Table 1. Approaches Used in Articles ( $\mathrm{n}=17)$ to Assess Interventions in Existing Courses

\begin{tabular}{|c|c|c|c|}
\hline Course & Intervention & Assessment(s) & Reference \\
\hline Pharmaceutical & Creation of six video & 1. Academic performance & 23 \\
\hline Calculations & $\begin{array}{l}\text { podcasts with a stepwise } \\
\text { demonstration of the } \\
\text { solution of the six most } \\
\text { challenging quiz problems }\end{array}$ & $\begin{array}{l}\text { 2. Survey about student } \\
\text { interaction with the intervention } \\
\text { and their perceptions about the } \\
\text { intervention. Survey included a } \\
\text { free-text item }\end{array}$ & \\
\hline $\begin{array}{l}\text { Integrated medicinal } \\
\text { chemistry and } \\
\text { pharmacology }\end{array}$ & $\begin{array}{l}\text { Five enrichment activities } \\
\text { were offered to students }\end{array}$ & $\begin{array}{l}\text { 1. Pre- and post-survey about } \\
\text { student perceptions and } \\
\text { confidence. Survey included }\end{array}$ & 35 \\
\hline Pharmacotherapy I & $\begin{array}{l}\text { Optional peer feedback } \\
\text { activity }\end{array}$ & $\begin{array}{l}\text { 1. Survey about student attitudes } \\
\text { and perceptions } \\
\text { 2. Qualitative: interviews }\end{array}$ & 42 \\
\hline $\begin{array}{l}\text { 5-week oncology } \\
\text { elective module }\end{array}$ & $\begin{array}{l}\text { An interactive activity was } \\
\text { created to represent various } \\
\text { oncology practice settings }\end{array}$ & $\begin{array}{l}\text { 1. A pre- and post-survey about } \\
\text { perceptions and confidence }\end{array}$ & 41 \\
\hline Basic and Clinical & Participation in optional & 1. Academic performance & 31 \\
\hline Pharmacogenomics & student-led study groups & $\begin{array}{l}\text { 2. Different surveys about } \\
\text { student perceptions were } \\
\text { administered pre- and post- } \\
\text { course }\end{array}$ & \\
\hline $\begin{array}{l}\text { Pharmaceutical } \\
\text { Calculations }\end{array}$ & $\begin{array}{l}\text { Provision of formative } \\
\text { feedback using video } \\
\text { podcasts versus typed } \\
\text { solutions }\end{array}$ & $\begin{array}{l}\text { 1. Survey about student } \\
\text { perceptions. Survey included } \\
\text { free-text items (qualitative } \\
\text { analysis) }\end{array}$ & 12 \\
\hline $\begin{array}{l}\text { Chemical Basis of Drug } \\
\text { Action }\end{array}$ & $\begin{array}{l}\text { Incorporation of Pharmacist } \\
\text { Patient Care Process }\end{array}$ & $\begin{array}{l}\text { 1. A pre- and post-survey about } \\
\text { student perceptions. The post- } \\
\text { survey encompassed additional } \\
\text { items about student perceptions, } \\
\text { which included some free-text } \\
\text { items (qualitative analysis) } \\
\text { 2. Pre- and post-test } \\
\text { 3. Student evaluations }\end{array}$ & 15 \\
\hline $\begin{array}{l}\text { Intermediate Pharmacy } \\
\text { Skills and Applications } \\
2\end{array}$ & $\begin{array}{l}\text { Mechanical and } \\
\text { mathematical challenges }\end{array}$ & $\begin{array}{l}\text { 1. Survey about student } \\
\text { confidence that also had free-text } \\
\text { items (qualitative analysis) }\end{array}$ & 16 \\
\hline
\end{tabular}


Sterile Compounding

Basic Communication

Skills for Pharmacy

Practice

Principles of Drug

Action I

Pharmacology and

Medicinal Chemistry 2

Pathophysiology

Principles of

Pharmacology

Skills laboratory

Pharmacotherapeutics
Changes to instruction and assessment methods (including simulations)

Incorporation of MyDispense (an online freeware) optional exercises

Addition of active learning exercises

Flipped classroom
approach
Incorporation of flipped
classroom activities

Banning of computers during class time

Addition of recitations to lectures

Addition of an activelearning session about pharmacogenomics

Flipped examination, i.e., students developed the assessment
1. Academic performance

2. Student evaluations that included free-text items

3. Changes in laboratory

expenses

1. Academic performance

18

2. Learning analytics

3. Survey about usage of intervention and perceptions.

Survey included free-text items

1. Pre- and post-PCRA-24

46

22

1. Academic performance

2. Student evaluations that included free-text items

1. Academic performance

2. Learning analytics

3. Survey about student perceptions

1. Academic performance

2. Course evaluations that included free-text items

1. Academic performance

20

2. Student evaluations that included free-text items

1. Academic performance

2. Pre- and post-survey about confidence. The post-survey encompassed additional items about perceptions, which included some free-text items

3. Pre- and post-test

1. Pre- and post-survey

2. Academic performance

3. Qualitative: focus groups

4. Student evaluations that

included free-text items

PCRA-24=Personal Report of Communication Apprehension 
Table 2. Approaches Used in Articles $(n=17)$ to Assess the Implementation of New Courses

\begin{tabular}{|c|c|c|}
\hline Course & Assessments & Reference \\
\hline PBL acute care elective & $\begin{array}{l}\text { 1. Academic performance } \\
\text { 2. Learning analytics } \\
\text { 3. Survey about perceptions that included free-text items }\end{array}$ & 37 \\
\hline $\begin{array}{l}\text { Pharmaceutical Care in } \\
\text { Indigenous Health } \\
\text { elective }\end{array}$ & $\begin{array}{l}\text { 1. Academic performance } \\
\text { 2. Student evaluations that included free-text items (qualitative } \\
\text { analysis) } \\
\text { 3. Enrollment data }\end{array}$ & 29 \\
\hline $\begin{array}{l}\text { Mental health first aid } \\
\text { elective }\end{array}$ & $\begin{array}{l}\text { 1. Pre- and post OMS-HC survey } \\
\text { 2. Qualitative: reflection }\end{array}$ & 43 \\
\hline $\begin{array}{l}\text { Surveys of Multi- } \\
\text { Modality Imaging } \\
\text { elective }\end{array}$ & $\begin{array}{l}\text { 1. Pre- and post-survey about confidence and perceptions } \\
\text { 2. Student evaluations that included free-text items }\end{array}$ & 44 \\
\hline $\begin{array}{l}\text { Health Promotion and } \\
\text { Disease Prevention } \\
\text { Across Cultures elective }\end{array}$ & $\begin{array}{l}\text { 1. Pre- and post-survey about confidence } \\
\text { 2. Pre- and post-test } \\
\text { 3. Academic performance }\end{array}$ & 38 \\
\hline $\begin{array}{l}\text { Pharmaceutical industry } \\
\text { practice elective }\end{array}$ & $\begin{array}{l}\text { 1. Pre- and post-survey about perceptions and confidence } \\
\text { 2. Academic performance } \\
\text { 3. Student evaluations }\end{array}$ & 32 \\
\hline Journal club elective & 1. Learning analytics & 47 \\
\hline $\begin{array}{l}\text { Aspects of Caring for } \\
\text { the Pain Patient elective } \\
\text { Drugs in Sport elective }\end{array}$ & $\begin{array}{l}\text { 1. Pre- and post-course survey about attitudes and perceptions } \\
\text { 2. Academic performance } \\
\text { 1. Survey about perceptions } \\
\text { 2. Qualitative: interviews }\end{array}$ & 39 \\
\hline $\begin{array}{l}\text { Women's reproductive } \\
\text { health elective }\end{array}$ & $\begin{array}{l}\text { 1. Academic performance } \\
\text { 2. Pre- and post-survey about perceptions and confidence } \\
\text { 3. Student evaluations }\end{array}$ & 28 \\
\hline $\begin{array}{l}\text { Advanced MTM } \\
\text { Certificate Course } \\
\text { elective }\end{array}$ & $\begin{array}{l}\text { 1. Academic performance } \\
\text { 2. Pre- and post-survey about perceptions and } \\
\text { values } \\
\text { 3. Survey about satisfaction }\end{array}$ & 33 \\
\hline $\begin{array}{l}\text { Ethnopharmacology of } \\
\text { Appalachia elective } \\
\text { Applied Secondary } \\
\text { Database Analysis } \\
\text { research elective }\end{array}$ & $\begin{array}{l}\text { 1. Academic performance } \\
\text { 2. Student evaluations } \\
\text { 1. Academic performance } \\
\text { 2. Survey about student satisfaction and confidence that } \\
\text { included free-text items }\end{array}$ & 27 \\
\hline $\begin{array}{l}\text { Academic Pharmacy } \\
\text { elective }\end{array}$ & $\begin{array}{l}\text { 1. Academic performance } \\
\text { 2. Student evaluations } \\
\text { 3. Student post-course reflections } \\
\text { 4. A survey, which included free-text items, } 1-2 \text { years after the } \\
\text { course }\end{array}$ & 36 \\
\hline $\begin{array}{l}\text { Creative Thinking for } \\
\text { Innovation elective }\end{array}$ & $\begin{array}{l}\text { 1. Pre- and post TTCT } \\
\text { 2. Academic performance } \\
\text { 3. Student evaluations that included free-text items }\end{array}$ & 49 \\
\hline $\begin{array}{l}\text { Cardiovascular } \\
\text { Electrophysiology: From } \\
\text { Bench to Bedside } \\
\text { elective }\end{array}$ & $\begin{array}{l}\text { 1. Academic performance } \\
\text { 2. Student evaluations that included free-text items }\end{array}$ & 25 \\
\hline $\begin{array}{l}\text { Diabetes Prevention } \\
\text { elective }\end{array}$ & $\begin{array}{l}\text { 1.Pre- and post-test } \\
\text { 2. Pre- and post-survey about confidence } \\
\text { 3. Qualitative: reflections } \\
\text { 4. Qualitative: focus groups }\end{array}$ & 48 \\
\hline
\end{tabular}

MTM=medication therapy management

OMS-HC=Opening Minds Scale for Health Care Providers

$\mathrm{PBL}=$ problem-based learning

TTCT=Torrance Test of Creative Thinking 
Table 3. A Summary of Approaches Used to Assess Course Interventions

\begin{tabular}{|c|c|c|c|c|c|}
\hline \multirow[t]{2}{*}{ Approach $^{+}$} & \multicolumn{2}{|c|}{ Changes in Existing Courses } & \multicolumn{2}{|c|}{$\begin{array}{l}\text { Implementation of New } \\
\text { Courses }\end{array}$} & \multirow[t]{2}{*}{$\begin{array}{l}\text { Total Frequency } \\
\text { (no., percent) }\end{array}$} \\
\hline & $\begin{array}{l}\text { Frequency } \\
\text { (no., percent) }\end{array}$ & References & $\begin{array}{l}\text { Frequency } \\
\text { (no., percent) }\end{array}$ & References & \\
\hline $\begin{array}{l}\text { Pre- and post- } \\
\text { survey }\end{array}$ & $7 / 17,41 \%$ & $\begin{array}{l}15,30,31,34,35,41, \\
46\end{array}$ & $8 / 17,47 \%$ & $\begin{array}{l}28,32,33,38,40,43, \\
44,48\end{array}$ & $15 / 34,44 \%$ \\
\hline Post survey & $6 / 17,35 \%$ & $12,16,18,19,23,42$ & $5 / 17,29 \%$ & $27,33,36,37,39$ & $11 / 34,32 \%$ \\
\hline $\begin{array}{l}\text { Academic } \\
\text { performance }\end{array}$ & $10 / 17,59 \%$ & $18-24,30,31,34$ & $12 / 17,71 \%$ & $\begin{array}{l}25-29,32,33,36-38 \\
40,49\end{array}$ & $22 / 34,65 \%$ \\
\hline $\begin{array}{l}\text { Student } \\
\text { evaluations }\end{array}$ & $6 / 17,35 \%$ & $15,20-22,24,30$ & $8 / 17,47 \%$ & $\begin{array}{l}25,26,28,29,32,36 \\
44,49\end{array}$ & $14 / 34,41 \%$ \\
\hline $\begin{array}{l}\text { Qualitative: } \\
\text { written }\end{array}$ & $3 / 17,18 \%$ & $12,15,16$ & $3 / 17,18 \%$ & $29,43,48$ & $6 / 34,18 \%$ \\
\hline Qualitative: oral & $2 / 17,12 \%$ & 30,42 & $2 / 17,12 \%$ & 39,48 & $4 / 34,12 \%$ \\
\hline Pre- and post-test & $2 / 17,12 \%$ & 15,34 & $3 / 17,18 \%$ & $38,48,49$ & $5 / 34,15 \%$ \\
\hline $\begin{array}{l}\text { Learning } \\
\text { analytics }\end{array}$ & $2 / 17,12 \%$ & 18,19 & $2 / 17,12 \%$ & 37,47 & $4 / 34,12 \%$ \\
\hline Other & $1 / 17,6 \%$ & 24 & $1 / 17,28 \%$ & 29 & $2 / 34,6 \%$ \\
\hline
\end{tabular}

${ }^{+}$Seventeen articles were identified for changes in existing courses and implementation of new courses; see Table 1 and Table 2 , respectively 